\title{
Langhian rays (Chondrichthyes, Batomorphii) from Brielas, Lower Tagus Basin, Portugal
}

\author{
$\begin{array}{llll}\text { P. FIALHO } & \text { A. BALBINO } & 1,2 & \text { M.T. ANTUNES } \\ & 2,3\end{array}$ \\ 'Departamento de Geociências, ECT, Universidade de Évora \\ Rua Romão Ramalho 59, 7000-671, Évora, Portugal \\ Fialho E-mail: prfialho181@gmail.com Balbino E-mail: acaceres@uevora.pt \\ ${ }^{2}$ Academia das Ciências de Lisboa \\ Rua da Academia das Ciências 19, 1249-122 Lisboa, Portugal \\ ${ }^{3}$ Faculdade de Ciências e Tecnologia, Universidade Nova de Lisboa \\ 2829-516 Caparica, Portugal. Antunes E-mail: mta@fct.unl.pt
}

The Langhian Vc unit of Brielas section (Caparica road, Almada), in the marine Miocene of the Lower Tagus Basin (West Portugal), is rich in batoid species. In this study, batoids are represented by 149 isolated fossil teeth and a single fossil dental plate collected from a bulk sample of washed and sorted sediment. A total of 12 species belonging to the orders Rhinopristiformes, Rajiformes, Torpediniformes and Myliobatiformes were identified. All genera and some species are known to have extant representatives. Aetobatus cappettai ANTUNES AND BALBINO, 2006, is described now from Langhian material which suggests it is older than previously supposed. The biogeographic ranges, environmental constraints and behaviour of the species described in this study point out to an infralittoral environment characterized by the dominance of warm water conditions, where episodic upwelling contributed to the occurrence of different types of batoids coexisting in the same habitat.

\section{INTRODUCTION}

The specimens described in this study were collected from the Middle Miocene marine beds of the Lower Tagus Basin that crop near the Costa de Caparica road, Almada city (Setúbal Peninsula, West Portugal), with geographical coordinates: $38^{\circ} 39^{\prime} 13.6^{\prime \prime} \mathrm{N}, 009^{\circ} 13$ '30.9'W. This outcrop,called Brielas, is very rich in fossil species of sharks and rays. The first reference to the Brielas outcrop was made by Antunes and Jonet (1970) in a study of sharks from Serravallian-Tortonian beds. More recently, Legoinha (2001) worked on the micropaleontology of this outcrop. The aim of the present study is to increase the knowledge of the Miocene Chondrichthyes present at Brielas.

According to Legoinha (2001) the fossiliferous beds exposed in this outcrop correspond to the Lisbon lithostratigraphic units Vc and Via (Fig. 1):

- Vc unit (base of Brielas section, about four meters thick) - yellowish sandy-silty beds, interbedded with fossilrich biocalcarenites. 
A

LithOSTRATIGRAPHY (COTteR, 1956)

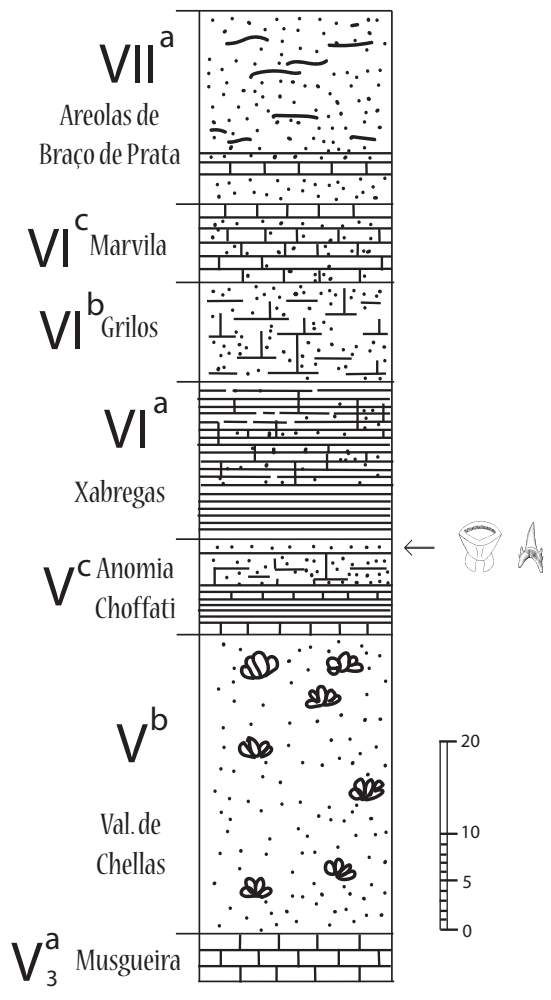

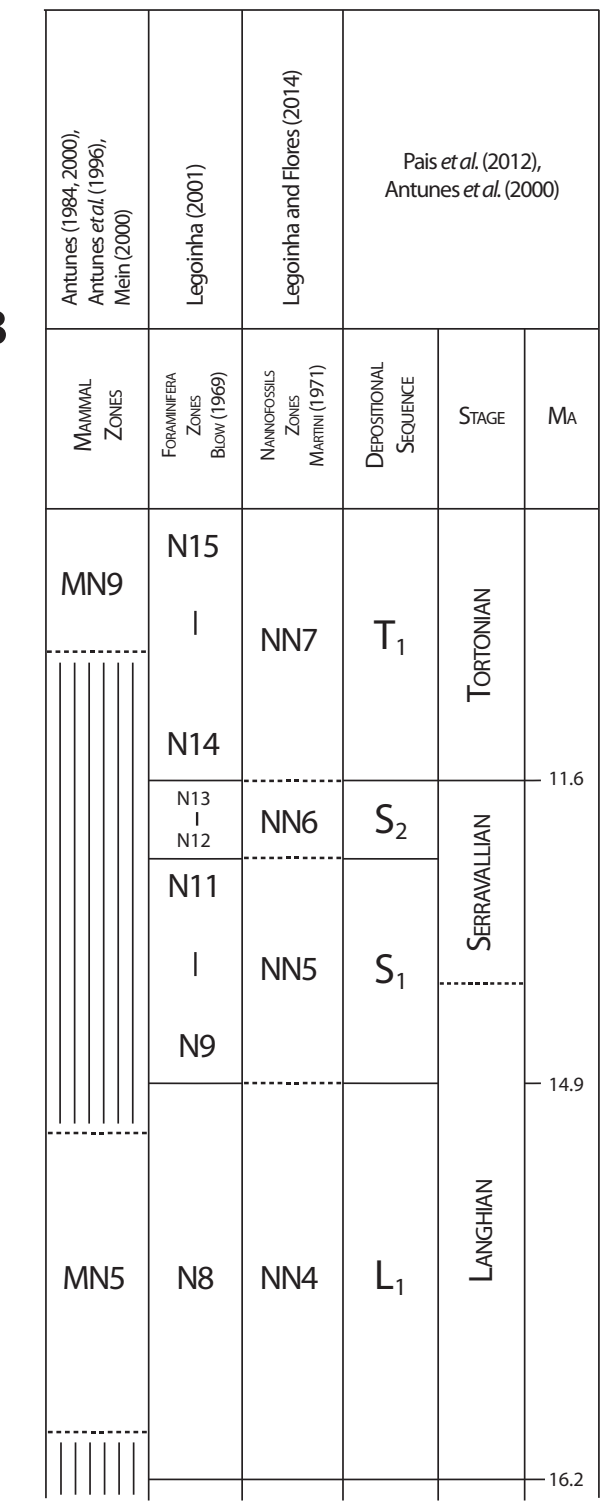

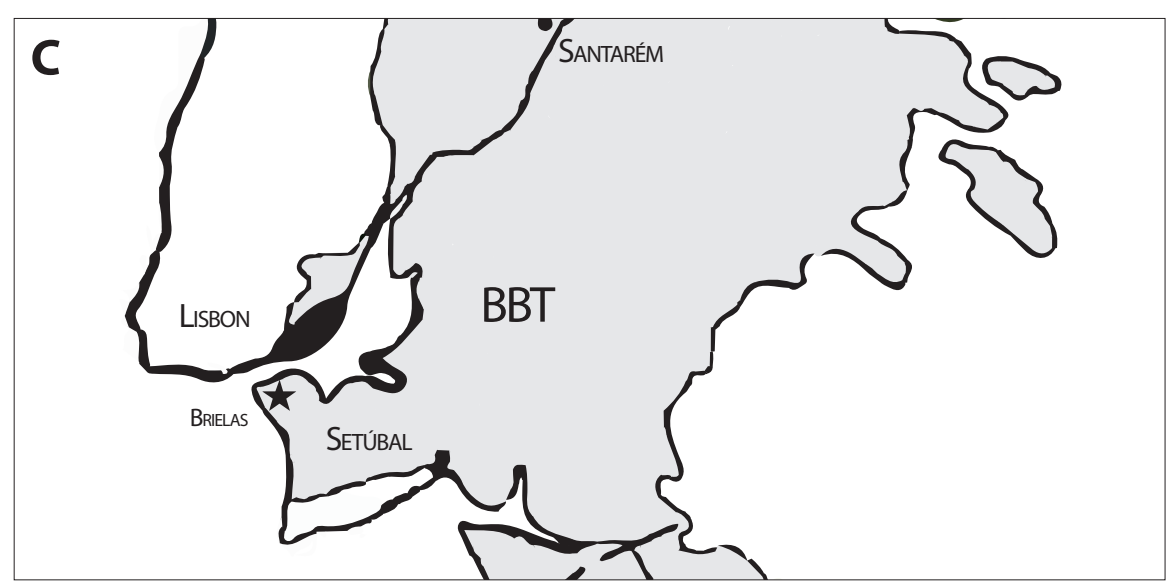

FIGURE 1. A) Stratigraphic position of the geological unit from which the sediments were collected (arrow) in a stratigraphic log located in Peninsula of Setúbal, Lower Tagus Basin, site of Brielas. Geological units: VIla, VIc, VIb, Vla, Vc, Vb, Va3. Scale in meters. B) Chronostratigraphic framework for the Middle to Upper Miocene of the Lower Tagus Basin. MN: Mammal Neogene zonation; N: Foraminifera zone; NN: Nannofossil zone; T: Tortonian; S: Serravalian; L: Langhian; Ma: megaannum. Scale in meters. C) Geographic position of the fossil site Brielas (geographical coordinates: 38³9'13.6” N, 009¹3'30.9”W). BBT: Lower Tagus Basin. 
- VIa unit (top of Brielas section, about 11 meters thick) - blue, fossil-poor clays interbedded with more carbonated banks rich in shell debris.

The sampling made in the basal part of the $\mathrm{Vc}$ unit (Fig. 1) by Legoinha (2001) yielded abundant planktonic foraminifera: Globigerina bulloides, G. praebulloides, Globigerinella aequilateralis, Globigerinoides immaturus, G. trilobus, Globorotalia peripheroronda, Orbulina suturalis, Praeorbulina glomerosa, $P$. transitora, Globoquadrina dehiscens, Dentoglobigerina altispira. This association is characteristic of the Langhian biozone N9 (15.1 to $13.82 \mathrm{Ma}$ ) (Legoinha, 2001). The ${ }^{87} \mathrm{Sr} / 86 \mathrm{Sr}$ dating of a scallop shell pointed to $14 \pm 0.4 \mathrm{Ma}$ age (Antunes et al., 1999b). These beds also record the depositional sequence S1 proposed by Antunes et al. (2000).

The Brielas outcrop is now inaccessible due to the construction works in the Costa da Caparica road. It is covered by dense vegetation and fully fenced.

\section{MATERIAL AND METHODS}

The sediment for this study was sampled in the Vc unit in the Brielas outcrop by Ausenda Balbino, in 1995, at M. Telles Antunes suggestion. A total of $93.5 \mathrm{~kg}$ were collected in the upper $50 \mathrm{~cm}$ of this unit. Sediment was disaggregated with hydrogen peroxide and washed with running water through sieves of decreasing mesh $(2.5 \mathrm{~mm}, 1.0 \mathrm{~mm}$, $0.5 \mathrm{~mm})$. The concentrate was then sorted and fossil items were described and identified.

The sample yielded 1,046 Teleostei fossils (not studied) and 2,168 Chondrichthyes fossils: 149 identified and 307 in analysis batoid teeth; 376 identified and 1,336 in analysis shark teeth. The studied specimens are housed in the Palaeontological Collections of the University of Évora, Portugal. Each taxon is stored in an individual numbered eppendorf unit or crystal box, depending on the size and amount of fossils. The labelling process follows the reference: UEBR (taxon number) (specimen number).

The photographic record of the fossils was made through three different processes depending on their size. Small teeth like those of Rhinobatos antunesi JONET, 1968 (Fig. 2H-K) were coated with gold prior to SEM photographic register. This record was performed with a VP-SEM-EDS HITACHI 3700N at the HERCULES Lab in Évora (Portugal) using an acceleration voltage of $10 \mathrm{kV}$ to $20 \mathrm{kV}$. Medium teeth like the ones of Aetobatus arcuatus AGASSIZ, 1843 (Fig.3E-F) were recorded by using a Leica EZ4W Stereo Zoom Microscope Integrated Camera. The larger ones such as the rostral tooth of Anoxypristis sp.
(Fig. 2A-C) were recorded with a photographic camera mounted on a tripod.

The classification proposed by Compagno (1973) and modified by Cappetta $(1987,2012)$ was adopted here, using, whenever necessary, updated taxonomic data available from Last et al. (2016a, b), Naylor et al. (2012) and Weigmann $(2016,2017)$, and the open nomenclature procedures of Bengtson (1988). Synonymy was gathered by analysing the information found at www.shark-references. com (Pollerspöck and Straube, 2018).

\section{SYSTEMATIC PALEONTOLOGY}

\author{
Class: Chondrichthyes HUXLEY, 1880 \\ Subclass: Elasmobranchii BONAPARTE, 1838 \\ Subcohort: Neoselachii COMPAGNO, 1977 \\ Superorder: Batomorphii CAPPETTA, 1980 \\ Order: Rhinopristiformes NAYLOR, CAIRA, JENSEN, \\ ROSANA, STRAUBEAND LAKNER, 2012 \\ Family: Pristidae BONAPARTE, 1838 \\ GENUS Anoxypristis WHITE AND MOY-THOMAS, 1941 \\ Anoxypristis sp. \\ Fig. 2A-C
}

Material. One rostral tooth (UEBR_1.1).

Description. The tooth is broken near the base. It is approximately $3 \mathrm{~cm}$ long and flattened dorso-ventrally, with sharp anterior and posterior edges (Fig. 2A, B). The tip of the tooth is slightly inclined. The morphology of the tooth suggests that its basal face had an elliptic shape (Fig. 2C) and the remaining area presents several foramina.

Discussion. The tooth was initially compared with the isolated rostral teeth of Anoxypristis mucrodens WHITE, 1926 and Pristis sp. figured by Cappetta (2012, pp. 394395, figs. $384 \mathrm{I}-\mathrm{M}$ and $385 \mathrm{I}-\mathrm{N}$ ) for the genus assessment. Although the tooth apex morphology resembles the one of the genus Pristis LINCK, 1790, it lacks the distinctly concave posterior edge characteristic of this selachians. For this reason, it was attributed to the genus Anoxypristis WHITE AND MOY-THOMAS, 1941. Only two of the three fossil species of this genus, Anoxypristis fajumensis STROMER, 1905, and Anoxypristis mucrodens WHITE, 1926, have been found in the Miocene (Pollerspöck and Straube, 2018). The studied tooth is more compressed dorso-ventrally than the rostral teeth of A. mucrodens (Cappetta, 2012, pp. 394-395, fig. 384 I-M) and of $A$. fajumensis figured by Stromer as Pristis fajumensis (1905, tafel VI, II, figs. 1-3). It is morphologically very similar to the rostral tooth of Anoxypristis sp. described by Zalmout et al. (2012, p. 79, fig. 5N). In the absence of more material, it is not possible to attribute this tooth to any species, hence it is left in open nomenclature. 


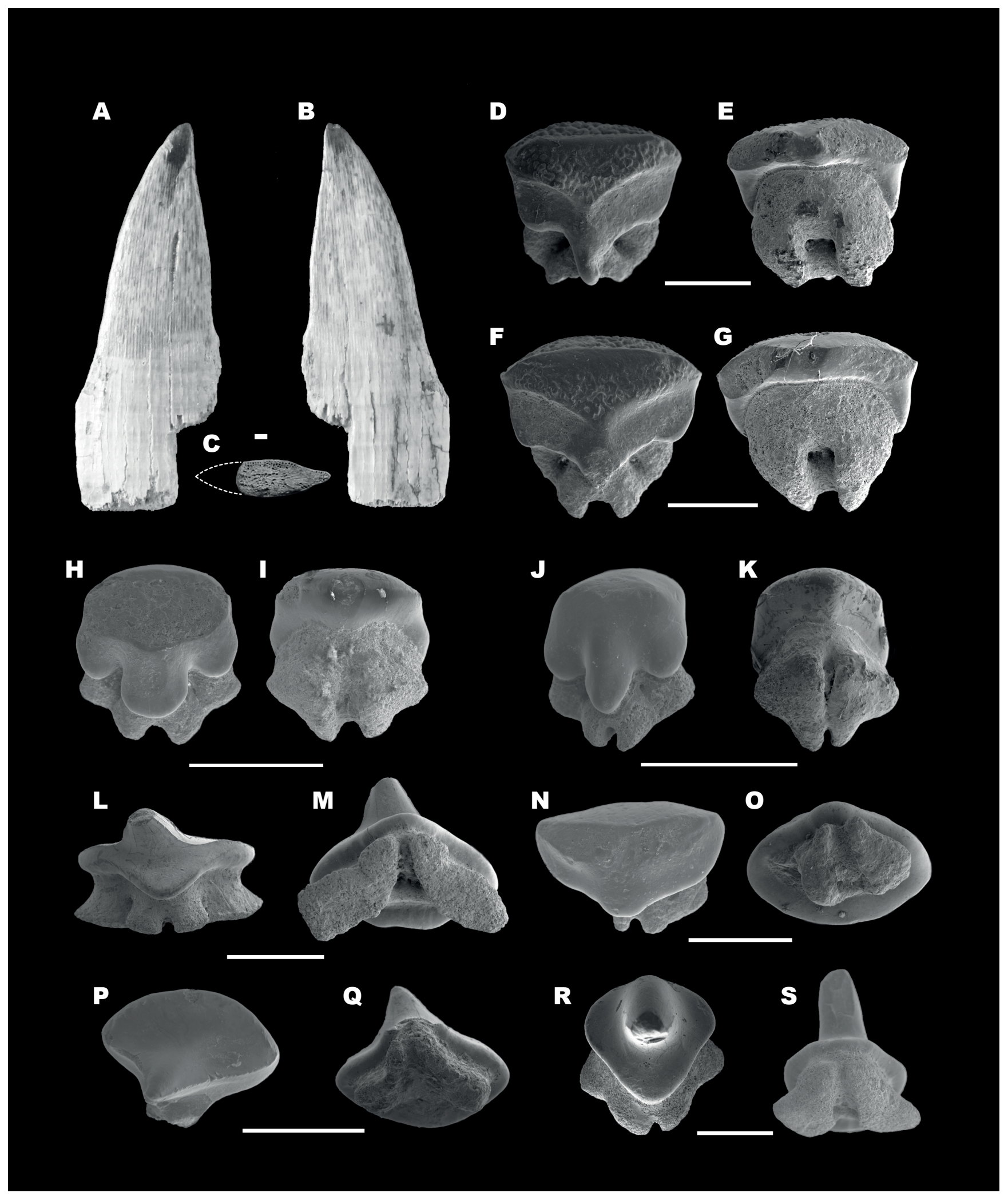

FIGURE 2. A-C) Anoxypristis sp. rostral tooth (UEBR_1.1): A) upper view, B) lower view and C) basal view. D, E) Rhynchobatus pristinus lateral tooth (UEBR_2.1): D) occlusal view and E) basal view. F, G) Rhynchobatus pristinus lateral tooth (UEBR_2.2): F) occlusal view and G) basal view. H, I) Rhinobatos antunesi tooth (UEBR_3.1): H) occlusal view and I) basal view. J, K) Rhinobatos antunesi tooth (UEBR_3.2): J) occlusal view and K) basal view. L, M) Raja olisiponensis tooth (UEBR_4.1): L) lingual view and M) basal view. N, O) Raja olisiponensis tooth (UEBR_4.2): N) occlusal view and $\mathrm{O}$ ) basal view. P, Q) Raja olisiponensis tooth (UEBR_4.3): P) occlusal view and Q) basal view. R, S) Raja olisiponensis tooth (UEBR_4.4): R) occlusal view and S) basal view. Scale bars: $1 \mathrm{~mm}$. 
Family: Rhinidae MÜLLER AND HENLE, 1841

GENUS Rhynchobatus MÜLLER AND HENLE, 1837

Rhynchobatus pristinus (PROBST, 1877)

Fig. 2D-G

1877. Pristis pristinus n. sp. - Probst, p.81, pl. 1, figs. 17-18.

Material. 28 teeth (UEBR_2.1 to UEBR_2.28).

Description. These are small and massive teeth, with approximately $2.5 \mathrm{~mm}$ of height in average. In occlusal view, they show a globular, rhomboid-shaped crown with rounded edges (Fig. 2D, F). In the oral face of the crown can be recognized three distinct areas, labial, central and lingual. The labial area is convex and the central area, which is separated from the labial area by a marked straight crest, is triangular. These two regions have a very distinct granular ornamentation that may be abraded. In occlusal view, the third area, the lingual face of the crown, is smooth and has a well-developed middle enameloid extension forming a long uvula. This central uvula may or may not protrude beyond the root groove (Fig. 2D, F). The root is massive and divided into two lobes by a deep, wide groove. The lingual face of the root presents a well-marked depression in each side of the uvula, with distinct lingual marginal foramina. In basal view, there are two or three main central foramina in the root groove, between the two lobes (Fig. 2E, G). The lobes are parallel and have flat basal faces.

Discussion. According to the shark-references database (Pollerspöck and Straube, 2018), there are currently three fossil species of Rhynchobatus described in the Miocene: Rhynchobatus pristinus PROBST, 1877; Rhynchobatus rudolffischeri LAURITO MORA, 1999; Rhynchobatus vincenti JAEKEL, 1894. The described teeth were compared with the individual teeth of $R$. rudolffischeri (Laurito Mora, 1999, pl. 28, figs.1-7). They differ from these specimens, in having more developed crowns, a longer central uvula and shorter roots. We also compared the studied material with isolated teeth of $R$. vincenti. The specimens figured by Bor (1985, p. 107, pl. 6, figs. 1-3) show some similarities with the studied specimens in the crown shape, length of the central uvula and root morphology. However, the latter do not have the distinct protuberance on the crown labial visor, seen in basal view, in $R$. vincenti. Between the anterior and lateral teeth of $R$. vincenti figured by Herman and Van Den Eeckhaut (2010, pl. 51) and the studied material are fewer similarities, the former have a less developed crown, a tenuous horizontal crest separating the labial area from the triangular central area, and a very short central uvula. We found that the fossil specimens of this study were very similar to several isolated antero-lateral, lateral and posterior teeth of $R$. pristinus figured by Cappetta (1970, pl. 23, figs. $17-27 ; 2012$, p. 336 , fig. $326 \mathrm{~A}-\mathrm{H})$ and to the lateral teeth of this species illustrated in Adnet and Cappetta (2011, p.
251, figs. 4, 2), Antunes and Balbino (2007, pl. 1, figs. 1, 2), Cicimurri and Knight (2009, p. 636, fig. 6A), Laurito Mora (1999, pl. 29, figs. 1-7) and Vialle et al. (2011, Fig. $4,2)$. In occlusal view, we can observe the same rhomboid shape of the crown, granular ornamentation, long central uvula and depressions on the root lobes. Abrasion or total absence of ornamentation in smaller specimens may be due to the ontogenetic heterodonty of $R$. pristinus as stated by Cicimurri and Knight (2009). Because the overall similar dental morphology of these specimens to $R$. pristinus, we attributed them to it.

Remarks. Rhynchobatus pristinus is an extinct species, thought to have been a nektobenthic carnivore, present in marine, coastal and even fluvial-deltaic habitats, according to the fossilworks database (Alroy, 2017).

Stratigraphic range. Oligocene to Miocene (Cicimurri and Knight, 2009).

Family: Rhinobatidae MÜLLER AND HENLE, 1838

GENUS Rhinobatos LINCK, 1790

Rhinobatos antunesi (JONET, 1968)

Fig. 2H-K

1968. Rhinobatus antunesi nov. sp. - Jonet, pl. I, figs. 6-a, 6-b, 6-c.

Material. Five teeth (UEBR_3.1 to UEBR_3.5).

Description. These are small teeth, with an average height of $1.3 \mathrm{~mm}$ and $1.2 \mathrm{~mm}$ wide. In occlusal view, the crown is globe-shaped, and may be flat because of functional wear or erosion (Fig. $2 \mathrm{H}$ ). The crown is wider than it is long, elongated in the middle, forming a uvula that does not reach the root notch. The middle uvula is flanked by two shorter expansions and is distinctly separated from them by a groove more or less wide. These three uvulas are rounded. In occlusal view, there are two root depressions, adjacent to the crown notches between the uvulas, and a margino-lingual foramen occurs on each depression (Fig. $2 \mathrm{H}, \mathrm{J})$. In basal view, the crown is slender and overhangs the root with a rounded enameloid bead (Fig. 2I, K). The root is thick and rather long. It is separated into two lobes by a subtle groove at the upper half, deepening into a small rounded indentation in the lower edge. The basal surface of the two lobes is sub-triangular in shape with rounded corners.

Discussion. Only two species of Rhinobatos have been found in the Miocene: Rhinobatos antunesi JONET, 1968 and Rhinobatos sahnii SAHNI AND MEHROTRA, 1981 (Pollerspöck and Straube, 2018). By comparing the studied specimens with the lateral teeth of Rhinobatos sp. described in Antunes and Balbino (2007, p. 111, pl. 1, figs. 3-8) we found that the specimen in Figure $5 \mathrm{~A}$ is extremely similar 
to the specimen of UEBR_3.1 (Fig. 2H, J) found at Brielas. However, the rest of the teeth depicted as Rhinobatos sp. have crowns less globulous and, in some of them, the middle uvula is longer and less round than the one observed in the studied specimens. The study material was also compared with the anterior and lateral teeth of $R$. antunesi figured by Jonet (1968, pl. I, fig. 6a-c) and Cappetta (1970, pl. 23, figs. 7-10), which are characterized by presenting globulous crowns with three round uvulas, the middle one being longer than the lateral ones, and two root lobes presenting a sub-triangular basal face. Since the studied specimens have the same morphology as these fossil teeth, we ascribe them to $R$. antunesi.

Remarks. Thought to have been a Miocene nektobenthic carnivore (Alroy, 2017).

\section{Stratigraphic range. Miocene (Alroy, 2017).}

Order: Rajiformes BERG, 1937

Suborder: Rajoidei GARMAN, 1913

Family: Rajidae BLAINVILLE, 1816

GENUS Raja LINNAEUS, 1758

Raja olisiponensis (JONET, 1968)

Fig. 2L-S

1968. Narcine olisiponensis nov. sp. - Jonet, pl. 1, fig. 7a, 7b, 7c, 9, 10, 11.

2008. Dipturus olisiponensis Jonet, 1968 BRISSWALTER, pl. 9, fig. 1-2.

2015. Rostroraja olisiponensis Jonet, 1968 ANDRIANAVALONA et al., p. 13, fig. 5A.

\section{Material. 34 teeth (UEBR_4.1 to UEBR_4.34).}

Description. Small teeth with an average width of approximately $2 \mathrm{~mm}$. The enameloid crown is smooth. In occlusal view, the base of the crown is circular to oval, depending on the position of the tooth. It overhangs the root peripherally, more marked at the lingual visor, leaning and forming a subtle bead or uvula (Fig. 2L, N, O, R). The crown has a curved cusp in its center, bent lingually and, in some cases, even beyond the lingual visor of the crown (Fig. 2R, S). In occlusal view, the lingual face of the crown is less developed than the labial face. They are separated by a marked transverse crest. The lingual face of the crown is strongly concave in profile, while the labial face is convex especially in the middle. The crown cusp is more or less elongated depending on the specimen. In basal view, the root is well developed but lower than the crown. It is divided into two lobes by a deep groove with several foramina (Fig. 2M, O, Q, S). The diverging root lobes outgrow the outline of the crown in most cases and are slightly concave. Each of them is vertically divided into two zones, different in size and shape, by a small notch in the outline (Fig. 2M).
Discussion. According to the shark-references database (Pollerspöck and Straube, 2018), only three species of Raja have been found in the Miocene: Raja gentili JOLEAUD, 1912; Raja holsatica REINECKE, VON DER HOCHT AND GÜRS, 2008; Raja olisiponensis (JONET, 1968). By comparing the studied specimens with the teeth of $R$. Gentili figured by Brisswalter (2008, pl. 9, fig. 3) and Cappetta (1970, pl. 20, figs. 28-31), we could see that the morphology was very different. The crown does not have a prominent cusp and the root lobes are not divided into two regions. The same was observed when the specimens were compared with the anterior and anterior-lateral teeth of $R$. holsatica figured by Reinecke et al. (2011, pl. 88, fig. 4, 5, pl. 89, fig. 2), where the overall morphology of the specimens is too different as well. The studied fossil teeth were also compared with the anterior and antero-lateral teeth from male and female specimens of Dipturus olisiponensis figured by Brisswalter (2008, pl. 9, figs. 1, 2) and Cappetta (2012, p. 359, fig. 348), lateral teeth of $R$. olisiponensis (Antunes and Balbino, 2007, pl. 2, figs. 1-4; García et al., 2014, p. 264, figs. 3, 5-8), and teeth of Narcine olisiponensis (Jonet, 1968, pl. 1, figs. 7a-c, 9-11). They are markedly similar, presenting a crown with a median bead, a marked cusp in male teeth and wider crowns in female teeth with a less developed transverse crest. Because the high similarity between the studied teeth and the specimens of $R$. olisiponensis (and synonymies), we can ascribe these fossils to this species.

Remarks. Raja olisiponensis is an extinct batoid species thought to have been a nektobenthic carnivore of marine habitats (Alroy, 2017).

Stratigraphic range. Neogene (Alroy, 2017).

Order: Torpediniformes DE BUEN, 1926

Superfamily: Torpedinoidea COMPAGNO, 1973

Family: Torpedinidae BONAPARTE, 1838

GENUS Torpedo HOUTTUYN, 1764

Torpedo sp.

Fig. 3A-B

\section{Material. One tooth (UEBR_5.1).}

Description. Only a single tooth was found, with a height of $0.9 \mathrm{~mm}$ per $1.4 \mathrm{~mm}$ of width. In occlusal view, the enameloid crown shows several many foramina, probably due to bioerosion (Fig. 3A). The crown is wide, with an almost rectangular shape, and a transverse crest developed into a long, sharp, slightly tilted cusp. In occlusal view, it is very symmetrical. Marginal angles are present. The lower edge of the labial visor of the crown is concave. The lingual visor of the crown, in occlusal view, is marked by a notch and exposes the limits of the root lobes (Fig. 3A). In basal view, the root is divided by a deep, wide groove into two small lobes, with a circular basal surface (Fig. 3B). 

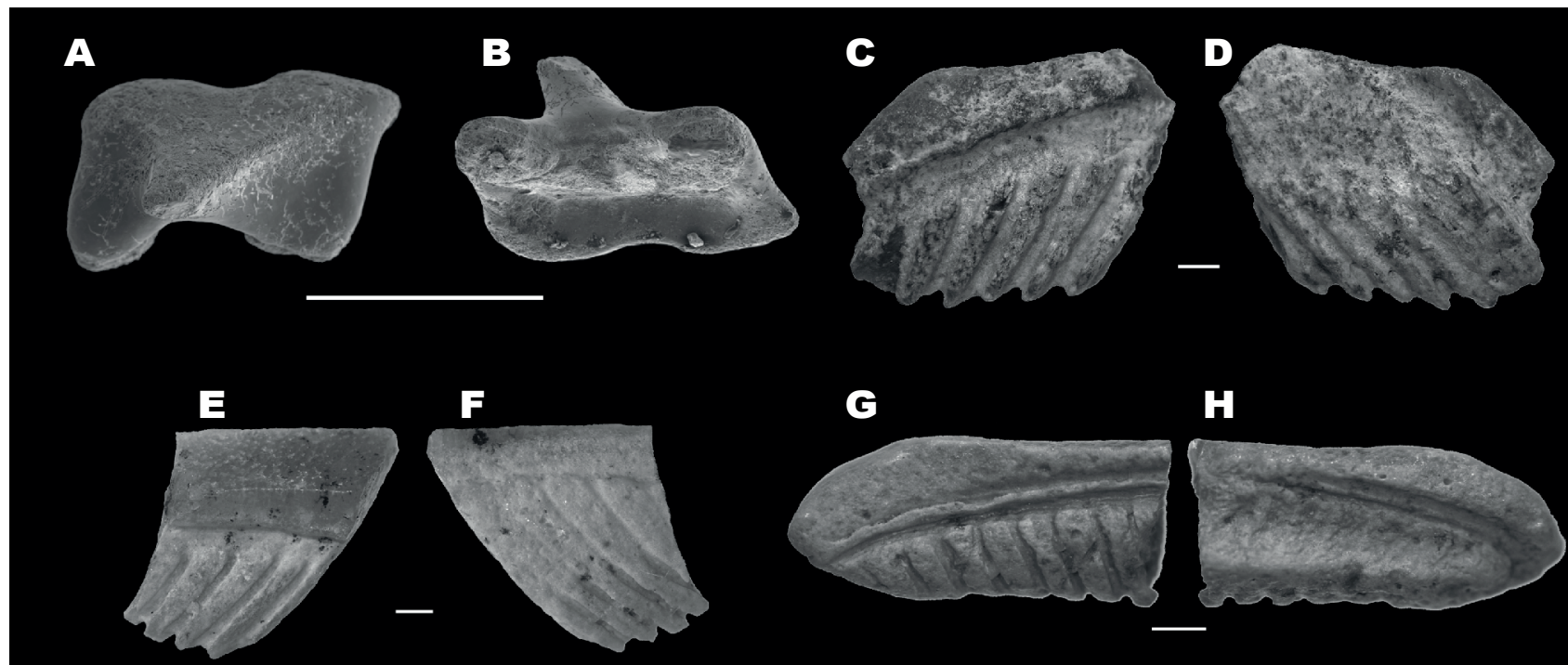

\section{$\mathbf{H}$}
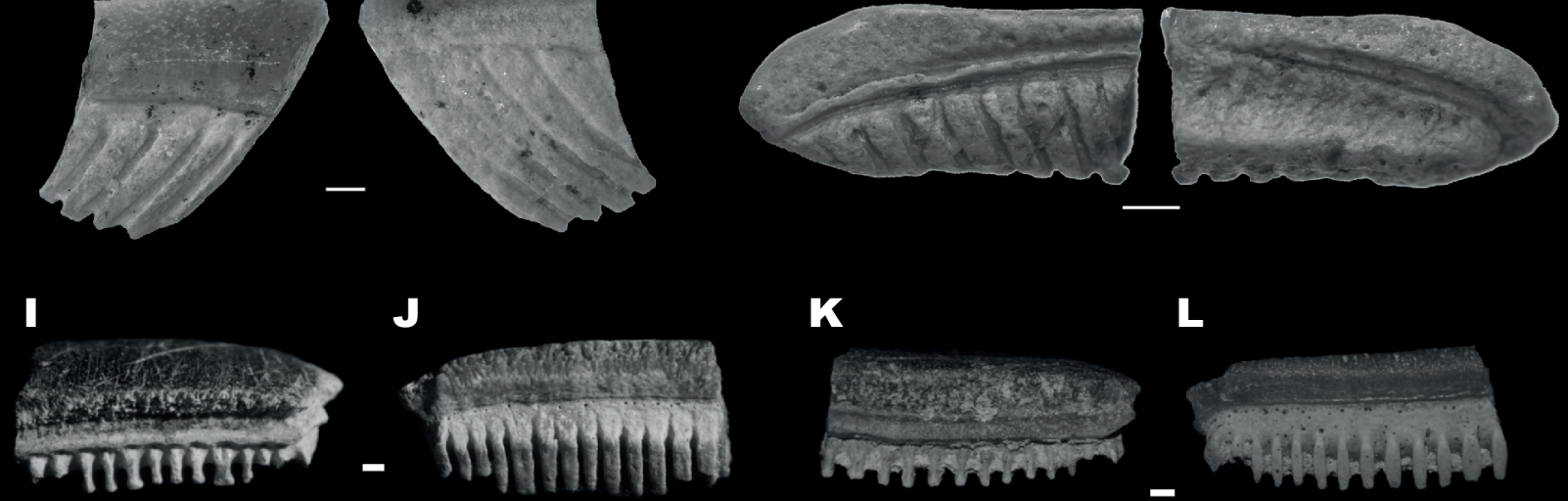

$\mathbf{K}$

$\mathbf{L}$
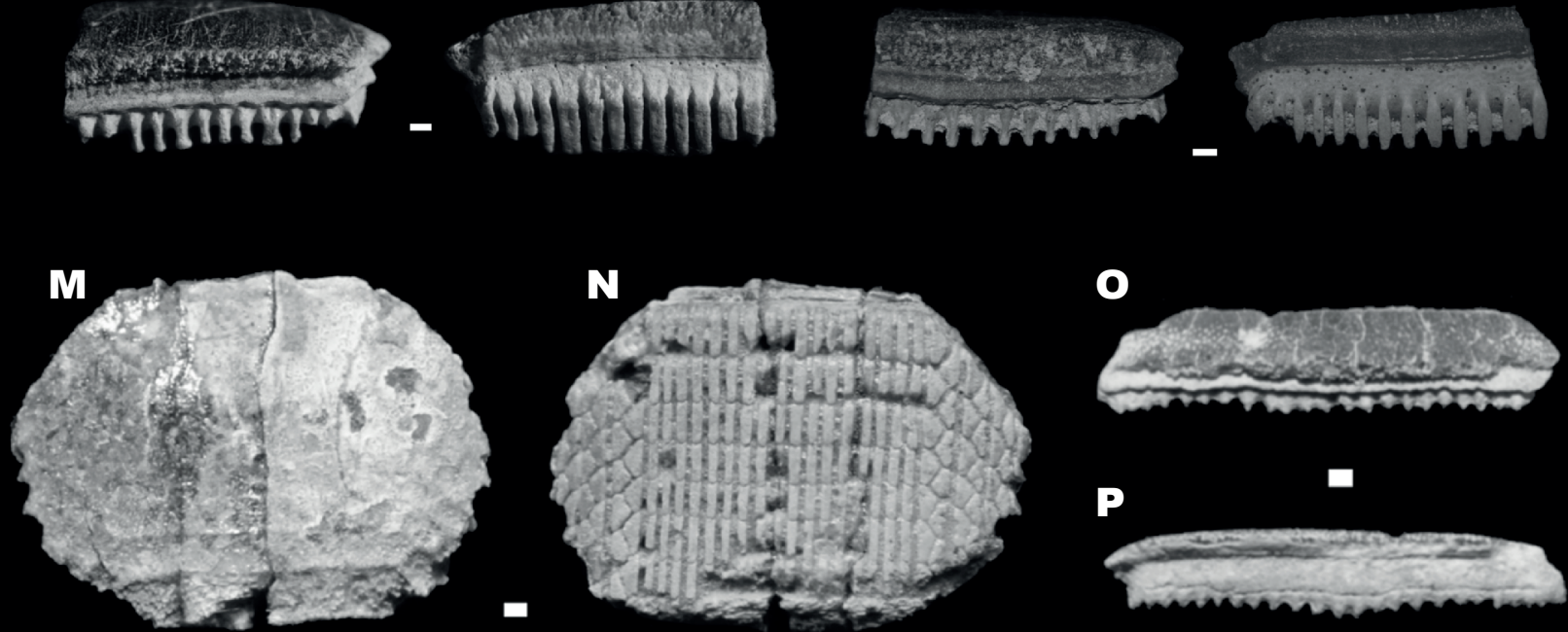

Q

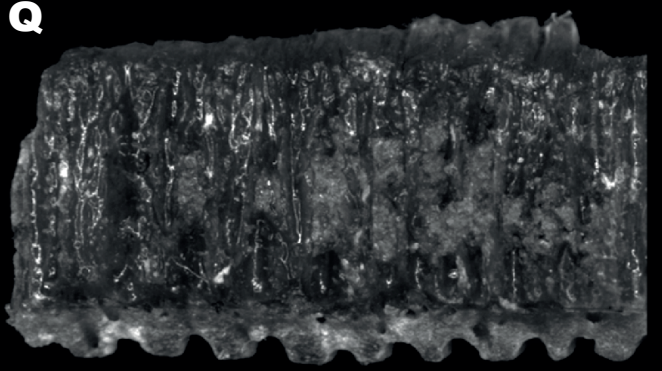

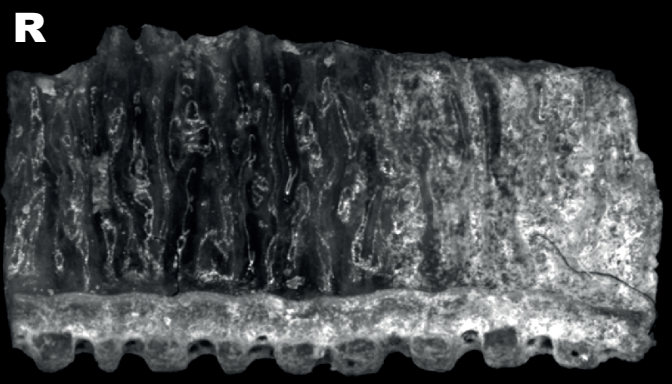

FIGURE 3. A, B) Torpedo sp. tooth (UEBR_5.1): A) occlusal view and B) basal view. C, D) Aetobatus arcuatus mandibular tooth (UEBR_6.1): C) lingual view and D) labial views. E, F) Aetobatus arcuatus mandibular tooth (UEBR_6.2): E) lingual view and F) labial view. G, H) Aetobatus cappettai upper tooth (UEBR_7.1): G) lingual view and H) labial view. I, J) Aetomylaeus sp. median tooth (UEBR_8.1): I) lingual view and J) labial view. K, L) Aetomylaeus sp. median tooth (UEBR_8.2): K) lingual view and L) labial view. M, N) Myliobatis sp. dental plate (UEBR_9.1): M) occlusal view and N) basal view. O, P) Myliobatis sp. median tooth (UEBR_9.2): 0) lingual view and P) labial view. Q, R) Mobula fragilis tooth (UEBR_10.1): Q) lingual view and R) labial view. Scale bars: $1 \mathrm{~mm}$. 
Discussion. According to the shark-references database (Pollerspöck and Straube, 2018) there are four fossil species of Torpedo. Only specimens left in open nomenclature have been described in the Miocene fossil record. This fossil tooth was compared with a lower antero-lateral male tooth of Torpedo torpedo (LINNAEUS, 1758) (Cappetta, 2012, p. 411, fig. 401, E-H) and the teeth of Torpedo sp. described by Antunes et al. (1999a). Although the crown and root of this specimen is very similar to the tooth of $T$. torpedo, nomenclature was left open because the lack of more material.

Order: Myliobatiformes COMPAGNO, 1973

Superfamily: Myliobatoidea COMPAGNO, 1973

Family: Myliobatidae BONAPARTE, 1838

GENUS Aetobatus BLAINVILLE, 1816

Aetobatus arcuatus (AGASSIZ, 1843)

Fig. 3C-F

1843. Aetobatis arcuatus Agassiz - fide Cappetta, pl. 24, figs. 6-9.

1858. Aetobatis tardiveli - Rouault, p. 101.

1867. Aetobatis profundus - Cope, p. 139.

1871. Aetobates omaliusi latidens - Delfortrie, pl. XI, fig. 42, A, a.

1871. Aetobates omaliusi curtidens - Delfortrie, pl. XI, figs. 43, A, a; 44, B, b; 45 C, c.

1904. Aetobatis biochei - Priem, p. 287, fig. 2.

Material. Two teeth (UEBR_6.1 and UEBR_6.2).

Description. These are fragments of mandibular teeth, with an average height of $7.7 \mathrm{~mm}$ and width of $6.7 \mathrm{~mm}$. They have a curvature that may imply an arched complete tooth. In lingual view, the crown is low and abraded. The surface of the crown is flat with straight edges. In one of the specimens it is possible to observe the alveolar ornamentation on the crown (Fig. 3E). In labial view, the crown is displaced labially in relation to the root, which is long and markedly distally inclined, comprising multiple grooves (Fig. 3D, F). The root blades and grooves are more distinct in lingual view (Fig. 3C, E).

Discussion. There are currently three species of Aetobatus described for the Miocene: Aetobatus arcuatus AGASSIZ, 1843; Aetobatus cappettai ANTUNES AND BALBINO, 2006; Aetobatus irregularis AGASSIZ, 1843. The two fossil teeth fragments were compared with the specimens of $A$. irregularis figured by Agassiz (1843, pl. 47, figs. 3-5), but while the Brielas teeth have crowns displaced labially in relation to the root, in A. irregularis the root is not markedly displaced, being even higher. When compared with the lower and superior teeth of A. cappettai (Antunes and Balbino, 2006, figs. 1-8) the curvature is similar in the lower teeth, but not as much as in the studied fossils. We also compared the material with the lower and superior median teeth of $A$. arcuatus figured by Cappetta (1970, pl. 24, figs. 6-9), Laurito Mora (2004, p.73, fig. 5b-c), Laurito and Valerio (2008, pl. 2, figs. 8, 9) and Szabóand Kocsis (2016, fig. 9A-C). The comparative analysis showed that the morphology of the studied teeth is very similar to that of the lower teeth of $A$. arcuatus and synonymies. Consequently, although they are only fragments of median lower teeth, they were attributed to $A$. arcuatus.

Remarks. Fossil nektobenthic carnivore ray found in marine and fluvial habitats (Alroy, 2017).

Stratigraphic range. Oligocene to Miocene (Alroy, 2017).

\section{Aetobatus cappettai ANTUNES AND BALBINO, 2006 Fig. 3G-H}

\section{Material. One tooth (UEBR_7.1).}

Description. Fragment of an upper tooth, 7.6mm long, narrow, slightly convex, and with a height of approximately $3.6 \mathrm{~mm}$. In lingual view, the crown is low with a prominent lateral extremity. There is a narrow edge separating the lingual face of the crown from the root (Fig. 3G). The root is flat and higher than the crown, with decreasing thickness towards the extremity. It has a polyaulacorhize root with shallow, narrow grooves separating the root blades. In labial view, the equally spaced root grooves are very shallow, almost imperceptibles, while in lingual view they are distinct until the extremity (Fig. 3G, H).

Discussion. The tooth was compared with the upper teeth of the three species of Aetobatus described for Miocene: Aetobatus arcuatus (Cappetta, 1970, pl. 24, figs. 6-9; Laurito, 2004, p.73, fig. 5b-c; Laurito and Valerio, 2008; Szabóand Kocsis, 2016); Aetobatus cappettai (Antunes and Balbino, 2006, figs. 1-8); Aetobatus irregularis (Agassiz, 1843, tab. 47, figs. 3-5). Despite being only one fragment of an upper tooth, the similarity with the teeth described by Antunes and Balbino (2006) is noticeable; it appears to correspond to an extremity of an upper tooth of $A$. cappettai, hence it was ascribed to this species.

Remarks. This fossil species is only known from the Miocene of Portugal (Alroy, 2017). This is the second time it has been described.

Stratigraphic range. Miocene (Cappetta, 2012).

GENUS Aetomylaeus GARMAN, 1908

Aetomylaeus sp.

Fig. 3I-L 
Material. Seven teeth (UEBR_8.1 to UEBR_8.7).

Description. These teeth show signs of abrasion, with a total height of $4.4 \mathrm{~mm}$ in average. In lingual view, the crown presents an alveolar ornamentation (Fig. 3I, K). In labial view, the root is higher than the crown, probably due to the abrasion of the latter (Fig. 3J, L). The lateral teeth are complete while the median teeth are broken. In occlusal view, the crown of the lateral teeth has an irregular hexagonal outline, and presents a marked visor protruding over the root. In basal view, the root has four blades. In labial view, it is possible to observe the arch present in the median teeth, the labial visor of the crown hanging over the labial face of the root, and the root displaced from the crown (Fig. 3J, L). In both views, it is possible to observe the polyaulacorhize root with its multiple blades separated by deep, wide grooves.

Discussion. According to the shark-references database (Pollerspöck and Straube, 2018), there are only two fossil species of the genus Aetomylaeus: Aetomylaeus cojimarensis ITURRALDE-VINENT, MORA, ROJAS AND GUTIERREZ, 1998, and Aetomylaeus cubensis IITURRALDEVINENT, MORA, ROJAS AND GUTIERREZ, 1998. The studied fossil teeth were compared with the lower and upper teeth of Aetomylaeus sp. (Cappetta, 2012, p. 446, fig. 439, C-D); A. cojimarensis and A. cubensis (Iturralde-Vinent et al., 1998), but we found the crown morphology to be dissimilar in all cases for both median and lateral teeth. In face to our current knowledge, we decided to leave this teeth in open nomenclature.

\section{GENUS Myliobatis CUVIER, 1816 Myliobatis sp. \\ Fig. 3M-P}

Material. 20 isolated teeth and one dental plate (UEBR_9.1 to UEBR_9.21).

Description. The dental plate is flat, with a variable height of approximately $5 \mathrm{~mm}$ in the middle decreasing to $2 \mathrm{~mm}$ towards the lateral teeth. It is well preserved, despite the abrasion of the crowns. In occlusal view, it is possible to distinguish seven rows of median and lateral teeth (Fig. $3 \mathrm{M})$. In basal view, the median teeth show polyaulacorhize roots and the lateral teeth holoaulacorhize roots (Fig. 3N). The individual median teeth, in occlusal view, are long and show an irregular hexagonal outline (Fig. 3M) and, in lingual view, it is possible to observe a tenuous ornamentation (Fig. 30). In labial view, these teeth are slightly arched (Fig. 3P). The crown is higher than the root, which is displaced from the crown, and the labial visor of the crown protrudes over the labial face of the root. The lateral teeth are smaller and present a hexagonal outline in occlusal view. In basal view, the root is exposed and divided into two lobes, displaced from the crown.
Discussion. The studied dental plate was compared with fossil upper and lower plates of Myliobatis aquila CUVIER, 1816 of male and female adult specimens (Herman et al., 2000, p. 19, text plate 8) and of a juvenile (Cappetta, 2012, p. 451, fig. 446, A-B); Myliobatis sp. (Sharmaand Patnaik, 2013, p. 165-166, figs. 2, 3); and some individual median and lateral teeth of Myliobatis toliapicus AGASSIZ, 1843 and Myliobatis sp. (Bor, 1985, pl. 8, figs. 1, 2 and 3-6). Since there are no distinctive features in the studied teeth that could be correlated with the material compared with, probably due to the poor preservation of the studied specimens, we decided to leave the nomenclature open.

Superfamily: Mobuloidea WHITLEY, 1936

Family: Mobulidae BONAPARTE, 1838

GENUS Mobula RAFINESQUE, 1810

Mobula fragilis (CAPPETTA, 1970)

Fig. 3Q-R

1970. Manta fragilis - Cappetta, pl. 26, figs. 10-11.

2009. Paramobula fragilis Cappetta, 1970 - Cicimurri and Knight, fig. 6, D.

Material. One tooth (UEBR_10.1).

Description. This is a very narrow tooth, with an extremely high and thin crown, with approximately $3.9 \mathrm{~mm}$ height per $6.7 \mathrm{~mm}$ width. It is compressed labio-lingually in profile view. In lingual view, the oral surface of the crown is broad but short (Fig. 3Q). In labial view, the anterior face of the crown is very high and vertical. It is marked by irregular vertical edges separated by narrow grooves. The anterior visor of the crown overlaps the root in labial view, creating a smooth depression between the crown and the root (Fig. $3 R$ ). In lingual view, the posterior face of the crown is marked by vertical ridges and it has a concave profile. The posterior visor of the crown is not very developed. The low root is polyaulacorhize. It has nine distinct blades separated by wide but shallow grooves, with different widths and depths.

Discussion. There are six fossil species of the genus Mobula (Pollerspöck and Straube, 2018), and all of them have been found in Miocene beds: Mobula cappettae JONET, 1976; Mobula fragilis CAPPETTA, 1970; Mobula lorenzolizanoi LAURITO MORA, 1999; Mobula loupianensis CAPPETTA, 1970; Mobula melanyae CASE, 1980; Mobula pectinata CAPPETTA, 1970. The specimen recovered was compared with $M$. lorenzolizanoi (Laurito Mora, 1999, pl. 39, figs. 2b, 3a-c, 4, 5a-b and pl. 40, fig. 3a-c), Manta melanyae (Case, 1980, pl. 10, figs. 1a-d, 2a-e), M. loupianensis (Brisswalter, 2008, pl. 9, figs. 5, 6 and pl. 10, fig. 10; Cappetta, 1970, pl. 26, figs. 1-6; Carrillo-Briceño et al., 2016, p.16, fig.12, 2-18) and M. pectinata (Cappetta, 1970, pl. 26, figs. 7-9) and we found no morphological similarities. However, when we compared the studied tooth 


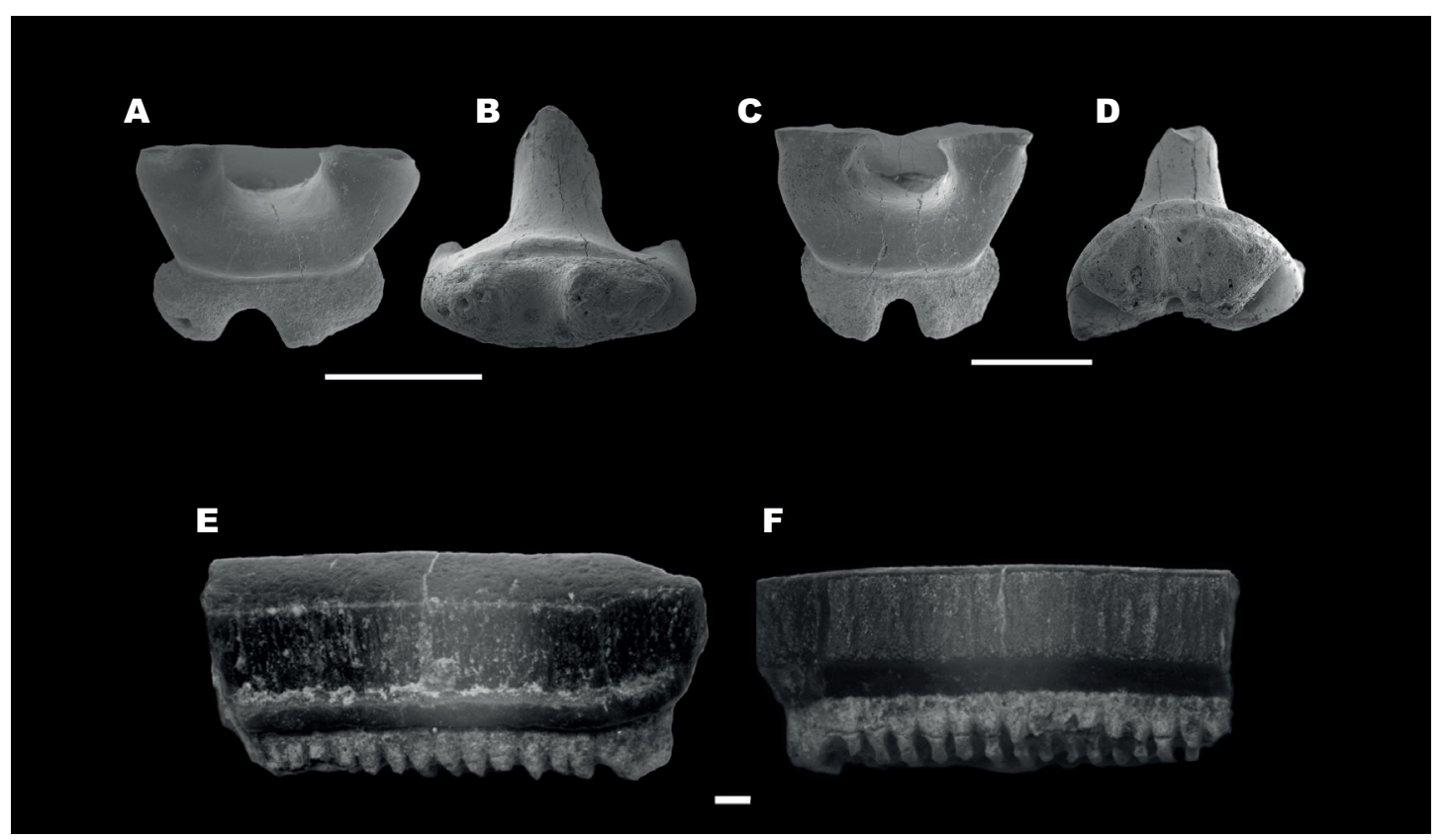

FIGURE 4. A, B) Mobula loupianensis anterior tooth (UEBR_11.1): A) occlusal and B) basal views. C, D) Mobula loupianensis lateral tooth (UEBR_11.2): C) occlusal view and D) basal view. E, F) Rhinoptera sp. median tooth (UEBR_12.1): E) lingual view and F) labial view. Scale bars: $1 \mathrm{~mm}$.

with the teeth of $M$. fragilis figured by Bor, Reinecke and Verscheren (2012, pl. 52, figs. 5-8) and Carrillo-Briceño et al. (2016, p.16, fig. 12, 1-11), Manta fragilis mentioned by Cappetta (1970, pl. 26, figs. 10, 11) and Paramobula fragilis cited by Cicimurri and Knight (2009, fig. 6D), we found that the morphology of the Brielas tooth was nearly identical to the morphology of these specimens. This justifies the attribution of this tooth to the species $M$. fragilis.

Remarks. The teeth of this fossil species are extremely fragile, so it is rare to find specimens that came through the fossilization process unscathed.

Stratigraphic range. Late Oligocene to Middle Miocene (Adnet et al., 2012).

\section{Mobula loupianensis CAPPETTA, 1970}

Fig. 4A-D

Material. Nine teeth (UEBR_11.1 to UEBR_11.9).

Description. These are small teeth, with an average height of $1.7 \mathrm{~mm}$ per $2.2 \mathrm{~mm}$ of width. In occlusal view, the anterior teeth have a broad crown marked by a transverse crest elongated in a posterior tip or cusp, broken in some specimens (Fig. 4A). The latero-posterior regions of the crown are slightly depressed and almost vertical. The posterior face of the crown has a concave profile and its visor slightly overhangs the root. In basal view, the root is high, subvertical and bilobed (Fig. 4B). The two lobes have a small basal surface. The lateral teeth are more transversely elongated, in occlusal view. The anterior section of the oral face of the crown may have small folds (Fig. 4C, D). The posterior tip or cusp is also present on the lateral teeth, despite being shorter and wider at the base. The lateroposterior regions of the crown are marked by depressions. Visible in both occlusal and basal views, the root presents two more developed lobes separated by a deep, wide groove.

Discussion. As indicated above all the six known fossil species of the genus Mobula have been found in the Miocene (Pollerspöck and Straube, 2018). The studied material was compared with specimens of Mobula lorenzolizanoi (Laurito, 1999, pl. 39, figs. 2b, 3a-c, 4, 5a-b and pl. 40, fig. 3a-c), Manta melanyae (Case, 1980, pl. 10, figs. 1a-d, 2a-e), Mobula loupianensis (Brisswalter, 2008, pl. 9, figs. 5, 6 and pl. 10, fig. 10; Cappetta, 1970, pl. 26, figs. 1-6; Carrillo-Briceño et al., 2016, p.16, fig.12, 1218), Mobula pectinata (Cappetta, 1970, pl. 26, figs. 7-9), Mobula fragilis (Bor et al., 2012, pl. 52, figs. 5-8; CarrilloBriceño et al., 2016, p.16, fig. 12, 1-11), Manta fragilis (Cappetta, 1970, pl. 26, figs. 10, 11) and Paramobula fragilis (Cicimurri and Knight, 2009, fig. 6D). The studied teeth are morphological more similar to the specimens of M. loupianensis than those of the other species, hence the attribution to this species.

Remarks. Mobula loupianensis was a nektobenthic carnivore that lived in coastal and reef habitats (Alroy, 2017). 

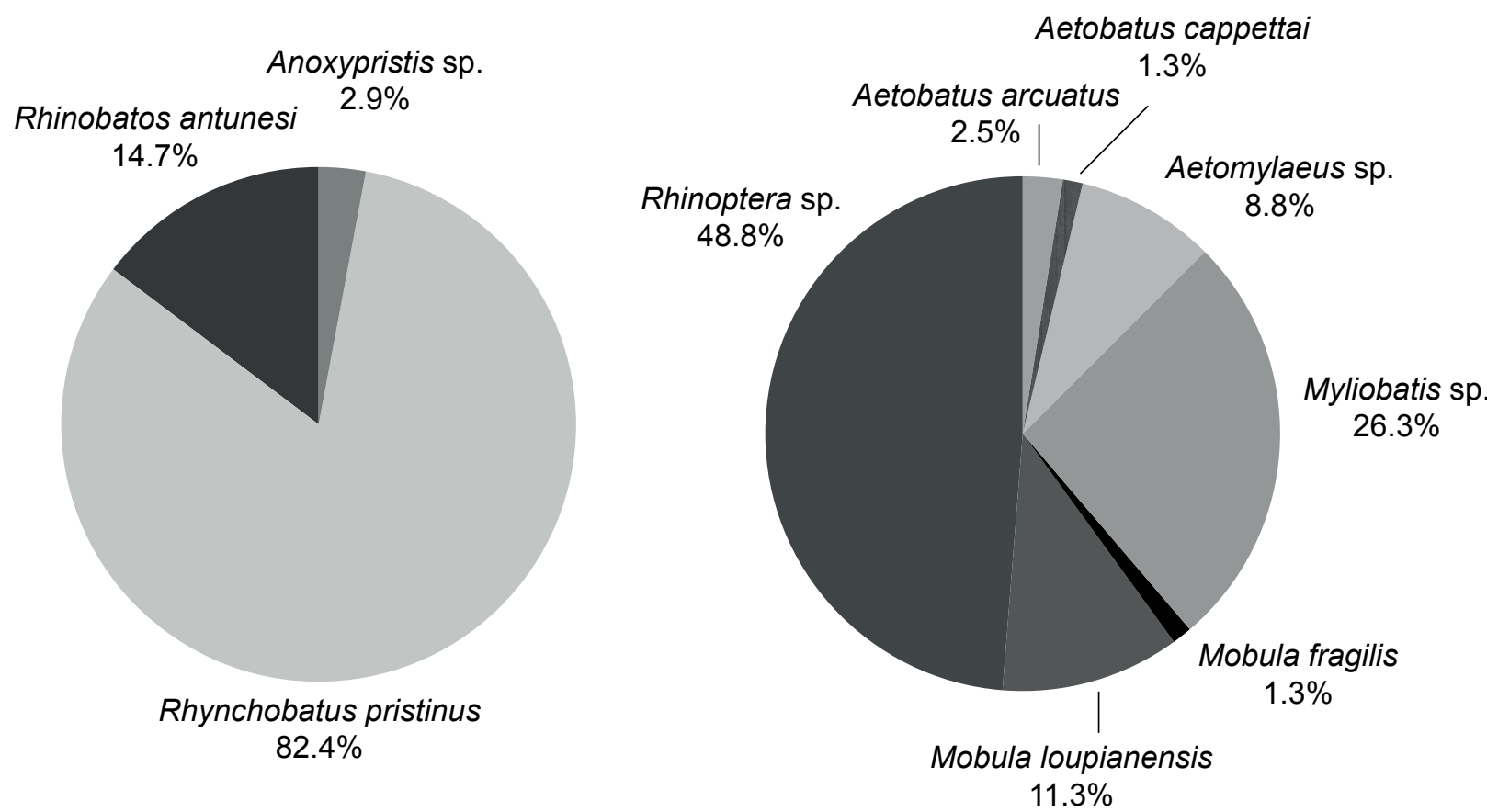

FIGURE 5. Graphic representation of the distribution of the studied material of Rhinopristiformes (on the left) and Myliobatiformes (on the right).

This is the second time that M. loupianensis has been described in the Neogene stratigraphic record of Portugal.

Stratigraphic range. Middle Miocene (Adnet et al, 2012).

Family: Rhinopteridae JORDAN AND EVERMANN, 1896

GENUS Rhinoptera CUVIER, 1829

Rhinoptera sp.

Fig. 4E-F

Material. 39 teeth (UEBR_12.1 to UEBR_12.39).

Description. Complete and fragmented median teeth, $1.5 \mathrm{~cm}$ long in average. In lingual view, the worn- out crown, has a hexagonal outline and alveolar ornamentation (Fig. $4 \mathrm{E})$. The root is low and aligned with the crown in profile. In labial view, these teeth are slightly arched in the middle (Fig. 4F). In both views, it is possible to observe the root multiple blades separated by grooves. The three complete lateral teeth, in profile, have a very low, worn-out crown. In occlusal view, the crown has a hexagonal outline. In basal view, the root is polyaulacorhnize, with multiple blades and deep grooves.

Discussion. There are eight fossil species of Rhinoptera (Pollerspöck and Straube, 2018), but only Rhinoptera raeburni wHITE, 1934, Rhinoptera schultzi HIDEN, 1995, Rhinoptera smithii JORDAN AND BEAL, 1913 and Rhinoptera studeri AGASSIZ, 1843, have been found in Miocene units. The studied teeth were compared with median individual teeth of $R$. cf. studeri Arambourg, 1952 and $R$. raeburni described by Sharmaand Patnaik (2013, p. 169, fig. 4H-J) and Rhinoptera sp. described by Brisswalter (2008). Due to their poor state of preservation, it was decided to leave them in open nomenclature.

\section{RESULTS}

The Middle Miocene batoid fauna from Brielas (Costa da Caparica, Portugal) is composed of 8 families, 10 genera and 12 species. The distribution of the studied material over the different species is shown in Table 1. The most diverse order is Myliobatiformes with 7 species, accounting for more than a half of the total fossil material (53.7\%), followed by Rhinopristiformes with three species (22.8\%), Rajiformes with one species (22.8\%) and Torpediniformes with one species and a single fossil tooth $(0.7 \%)$ (Fig. 5).

\section{DISCUSSION}

The Brielas outcrop with its 12 species of batoids described from a bulk sample of 149 teeth can be considered a very rich paleontological site. Legoinha (2001) characterized the local sedimentary succession as typical of an infralittoral environment of moderately warm waters, with increasing depth upwards, transitioning to a circalittoral environment. The predominance of demersal batoids (benthic and benthopelagic forms) like Rhynchobatus, Myliobatis and Rhinoptera, 


\begin{tabular}{|c|c|c|c|c|}
\hline Order & Family & Species & Fossils & Frequency \\
\hline \multirow[t]{3}{*}{ Rhinopristiformes } & Pristidae & Anoxypristis sp. & 1 & $0.7 \%$ \\
\hline & Rhinidae & Rhynchobatus pristinus & 28 & $18.8 \%$ \\
\hline & Rhinobatidae & Rhinobatos antunesi & 5 & $3.4 \%$ \\
\hline Rajiformes & Rajidae & Raja olisiponensis & 34 & $22.8 \%$ \\
\hline Torpediniformes & Torpedinidae & Torpedo sp. & 1 & $0.7 \%$ \\
\hline \multirow[t]{7}{*}{ Myliobatiformes } & Myliobatidae & Aetobatus arcuatus & 2 & $1.3 \%$ \\
\hline & & Aetobatus cappettai & 1 & $0.7 \%$ \\
\hline & & Aetomylaeus sp. & 7 & $4.7 \%$ \\
\hline & & Myliobatis sp. & 21 & $14.1 \%$ \\
\hline & Mobulidae & Mobula fragilis & 1 & $0.7 \%$ \\
\hline & & Mobula loupianensis & 9 & $6.0 \%$ \\
\hline & Rhinopteridae & Rhinoptera sp. & 39 & $26.2 \%$ \\
\hline & & & 149 & $100 \%$ \\
\hline
\end{tabular}

TABLE 1. Absolute and relative frequencies of the batoid species sampled in the Langhian outcrop at Brielas, Costa da Caparica, West Portugal.

characteristics of tropical to temperate littoral and neritic zones, coexisting with genera of colder environments such as Raja and pelagic forms such as Mobula (Last et al., 2016b), further reinforces this interpretation. In addition, both batoid rich infralittoral and circalittoral environments could be related to a possible upwelling activity. This process allows the mixing and overlapping of water bodies with different mean values of salinity and temperature, including cold, deep bodies of water, rich in nutrients, that rise to replace shallow warmer bodies poor in nutrients (Kosro et al., 1991). This phenomenon increases the biological productivity of surface waters (Cushing, 1969), attracting demersal and pelagic species, and may explain the presence of such association of batoids in these waters.

\section{CONCLUSIONS}

The Vc unit of Brielas section is rich in selachians forms, with the fossil material associated with batoid organisms (456) accounting for $21.0 \%$ of the total material found in the studied sample. The four orders of Batomorphii selachians, Rhinopristiformes, Rajiformes, Torpediniformes, and Myliobatiformes, are present with a total of 10 genera and 12 species: Anoxypristis sp.; Rhynchobatus pristinus; Rhinobatos antunesi; Raja olisiponensis; Torpedo sp.; Aetobatus arcuatus; Aetobatus cappettai; Aetomylaeus sp.; Mtliobatis sp.; Mobula fragilis; Mobula loupianensis and Rhinoptera sp. Myliobatiformes is the predominant order with 7 species accounting for $53.7 \%$ of the identified batoid material, and Rhinoptera the commonest occurring genus (Fig. 5).

Interestingly, a fossil tooth of Mobula fragilis was found in the studied sediments; due to its unique morphology, it is not usual to find fossil teeth of this genus in a good state of preservation.

The studied sample is also characterized by the presence of batoid forms from typically distinct climatic and bathymetric zones. The depositional environment has been described by Legoinha (2001) as in transition from infralittoral to circalittoral. This occurrence may be explained by upwelling activity which attracts a great faunal diversity.

Further research on the Vc unit in other outcrops would provide a better understanding of the biodiversity and distribution of the Langhian Elasmobranchii species in Portugal. 


\section{ACKNOWLEDGMENTS}

We are grateful to the University of Évora for providing the laboratory facilities for sediment treatment, and to José Mirão, Luis Dias and Lúcia Rosado of HERCULES Lab for the photographic record of most specimens with a VP-SEMEDS HITACHI 3700N. The authors thank Prof. Henri Cappetta and his colleagues at the Institut des Sciences de l'Évolution de Montpellier (ISEM), Université de Montpellier, for all the knowledge shared during a week internship in October 2016. We would also like to acknowledge Prof. Legoinha for his help with the chronostratigraphic framework of the site, and the referees whose observations have been most helpful.

\section{REFERENCES}

Adnet, S., Cappetta, H., Guinot, G., Notarbartolo di Sciara, G., 2012. Evolutionary history of the devil rays (Chondrichthyes: Myliobatiformes) from fossil and morphological inference. Zoological Journal of the Linnean Society, 166(1), 132-159. DOI: https://doi.org/10.1111/j.1096-3642.2012.00844.

Agassiz, L., 1843 (1833-1843). Recherches sur les poissons fossiles. Tome III: contenant l'histoire de l'ordre des Placoïdes. Neuchatel, Suisse. Imprimerie de Petitpierre.

Alroy, J., 2017. Fossilworks. Gateway to the paleobiology database. Website: www.fossilworks.org. Last accessed: version 07/2017.

Andrianavalona, T.H., Ramihangihajason, T.N., Rasoamiaramanana, A., Ward, D.J., Ali, J.R., Samonds, K.E., 2015. Miocene Shark and Batoid Fauna from Nosy Makamby (Mahajanga Basin, Northwestern Madagascar). PLOS ONE, 10(6). DOI: https:// doi.org/10.1371/journal.pone.0129444

Antunes, M.T., Jonet, S., 1970. Requins de l'Helvétien Supérieur et du Tortonien de Lisbonne. Revista da Faculdade de Ciências da Universidade de Lisboa, 2nd series, C, 16(1), 119-280.

Antunes, M.T., 1984. Essai de synthèse sur les mammifères du Miocêne du Portugal. Recherche sur les Civilisations, Paris, vol. d'Hommage au géologue G. Zbyszewski, 301-323.

Antunes, M.T., Legoinha, P., Nascimento, A., Pais, J., 1996. The evolution of the Lower Tagus basin (Lisbon and Setúbal Peninsula, Portugal) from Lower to early Middle Miocene. Géologie de la France, 4, 59-77.

Antunes, M.T., Balbino, A.C., Cappetta, H., 1999a. Sélaciens du Miocene terminal du Bassin d'Alvalade (Portugal). Essai de synthèse. Ciências da Terra, 13, 115-129.

Antunes, M.T., Elderfield, H., Legoinha, P., Nascimento, A., Pais, J., 1999b. A Stratigraphic framework for the Miocene from the Lower Tagus Basin (Lisbon, Setúbal Peninsula, Portugal). Depositional sequences, biostratigraphy and isotopic ages. Revista de la Sociedad Geologica de España, 12(1), 3-16.

Antunes, M.T., 2000. Miocene mammals from Lisbon and geologic age. A showcase for marine-continental correlations. Ciências da Terra/Earth Sciences Journal, 14, 343-348.
Antunes, M.T., Legoinha, P., Proença Cunha, P., Pais, J., 2000. High resolution stratigraphy and miocene facies correlation in Lisbon and Setúbal Península (Lower Tagus Basin, Portugal). Ciências da Terra, 14, 183-190.

Antunes, M.T., Balbino, A.C., 2006. Latest Miocene Myliobatids (Batoidei, Selachii) from the Alvalade Basin, Portugal. Cainozoic Research, 4(1-2), 41-4.

Antunes, M.T., Balbino, A.C., 2007. Rajiformes (Neoselachii, Batomorphii) from the Alvalade Basin, Portugal. Annales de Paléontologie, 93(1), 107-119. DOI: https://doi.org/10.1016/j. annpal.2007.03.002

Arambourg, C., 1952. Les vertébrés fossiles des gisements de phosphates (Maroc-Algérie-Tunisie). Notes et Mémoires du Service Géologique du Maroc, 92, 1-372, 62fig., 44pl.

Balbino, A., 1995. Seláceos (Pisces) do Miocénico Terminal da Bacia de Alvalade (Portugal): Sistemática, Ecologia, Paleoambientes, Comparação com faunas actuais. Unpublished PhD Thesis. Universidade de Évora, 200pp.

Bengtson, P., 1988. Open nomenclature. Paleontology, 31(1), 223227.

Berg, L.S., 1937. A classification of fish-like vertebrates. Bulletin of the Academy of Sciences of URSS, Biology Series, 4, 1277-1280.

Blainville, H.M., 1816. Prodrome d'une nouvelle distribution systématique du règne animal. Bulletin des Sciences, Société Philomatique de Paris, 8, 105-112 + 121-124.

Blow, W.H., 1969. Late middle Eocene to recent planktonic foraminiferal biostratigraphy. In: Bronnimann, P., Renz, H.H. (eds.). Proceedings of the $1^{\text {st }}$ International Conference on Planktonic Microfossils, Geneva, 1, 199-422.

Bonaparte, C.L., 1838. Selachorum tabula analytica. Nuovi Annali della Science Naturali Bologna, 1(2), 195-214.

Bor, T.J., 1985. Elasmobranch teeth (vertebrata, pisces) from the Dongen formation (Eocene) in the Netherlands. Mededelingen van de Werkgroep voor Tertiaire en Kwartaire Geologie, 22, 73-122.

Bor, T., Reinecke, T., Verschueren, S., 2012. Palaeontos 21: Miocene Chondrichthyes from Winterswijk - Miste, the Netherlands. United Kingdom, Palaeo Publishing and Library vzw, 194pp.

Brisswalter, G., 2008. Inventaire des Élasmobranches (requins, raies, chimères) des dépôts molassiques du Sud-Luberon (Miocène supérieur), Cabrières-d'Aigues (Vaucluse) France. Lubeon, Parc natural régional du Luberon, 100pp.

Cappetta, H., 1970. Les Sélaciens du Miocène de la région de Montpellier. Palaeovertebrata, Mémoire Extraordinaire. Montpellier, Laboratoire de Paléontologie, 139pp.

Cappetta, H., 1980. Les Sélaciens du Crétacé supérieur du Liban. II. Batoïdes. Palaeontographica, Abteilung A, 168(5-6), 149229.

Cappetta, H., 1987. Chondrichthyes II. Mesozoic and Cenozoic Elasmobranchii, Germany, Handbook of Paleoichthyology, Volume 3B. Verlag Dr. Friedrich Pfeil, 193pp.

Cappetta, H., 2012. Chondrichthyes: Mesozoic and Cenozoic Elasmobranchii teeth. Germany, Handbook of Paleoichthyology, Volume 3E. Verlag Dr. Friedrich Pfeil, 512pp. 
Carrillo-Briceño, J.D., Aguilera, O.A., De Gracia, C., AguirreFernández, G., Kindlimann, R., Sánchez-Villagra, M.R., 2016. An early Neogene elasmobranch fauna from the southern Caribbean (western Venezuela). Palaeontologia Electronica, 19(2), 1-32. DOI: https://doi.org/10.26879/664

Case, G.R., 1980. A Selachian fauna from the Trent Formation, Lower Miocene (Aquitanian) of Eastern North Carolina. Palaeontographica, Abteilung A, 171, 75-103.

Cicimurri, D.J., Knight, J.L., 2009. Late Oligocene sharks and rays from the Chandler Bridge Formation, Dorchester County, South Carolina, USA. Acta Palaeontologica Polonica, 54(4), 627-647. DOI: https://doi.org/10.4202/app.2008.0077

Compagno, L., 1973. Interrelationships of living elasmobranchs. In: Greenwood, P.H., Miles, R.S., Patterson, C. (eds.). Interrelationships of Fishes. Zoological Journal of the Linnean Society, 53 (Supplement 1), 15-61.

Compagno, L.J., 1977. Phyletic relationships of living sharks and rays. American Zoolologist, 17(2), 303-322.

Cope, E.D., 1867. An addition to the vertebrate fauna of the Miocene period, with a synopsis of the extinct Cetacea of the United States. Proceedings of the Academy of Natural Sciences of Philadelphia, 19(4), 138-157.

Cotter, J.C.B., 1956. O Miocénico marinho de Lisboa. Lisboa, Comunicações dos Serviços Geológicos de Portugal, XXXVI (Supplement), 170pp.

Cushing, D.H., 1969. Upwelling and fish production. FAO Fisheries Technical Paper, 84, 40.

Cuvier, G.L., 1816. Le Règne Animal distribué d'après son organisation pour servir de base à l'histoire naturelle des animaux et d'introduction à l'anatomie comparée. Les reptiles, les poissons, les mollusques et les annélides. Paris, Déterville, 532pp.

Cuvier, G.L., 1829. Le règne animal, distribué d'après son organisation, pour servir de base à l'histoire naturelle des animaux et d'introduction à l'anatomie comparée. Nouvelle édition, revue et augmentée. Tome II. Paris, Chez Déterville, 406pp.

De Buen, F, 1926. Catálogo ictiológico del Mediterráneo español y de Marruecos recopilando lo publicado sobre peces de las costas mediterráneas y próximas del Atlántico (Mar de España). Madrid, Memorias del Instituto Español de Oceanografía (Resultados de las Campañas realizadas por acuerdos internacionales), 2, 1-221.

Delfortrie, E., 1871. Les broyeurs du Tertiaire aquitanien. Actes de la Société linnéenne de Bordeaux, 28, 213-236.

García, E., Balbino, A., Antunes, M.T., Ruiz, F, Civis, J., Abad, M., Toscano-Grande, A., 2014. Los Rajiformes (Chondrichthyes, Batomorphii) del Plioceno inferior de la Formación Arenas de Huelva, suroeste de España. Ameghiniana, 51(3), 259-265. DOI: https://doi.org/10.5710/AMGH.14.01.2014.608

Garman, S., 1908. New Plagiostomia and Chismopnea. Bulletin of the Museum of Comparative Zoology at Harvard College, $51,249-256$.

Garman, S., 1913. The Plagiostomia (Sharks, Skates and Rays). Memoirs of the Museum of Comparative Zoolology at Harvard College, 36(1-2), 528pp.
Herman, J., Hovestadt-Euler, M., Hovestadt, D.C., Stehmann, M., 2000. Contributions to the study of the comparative morphology of teeth and other relevant ichthyodorulites in living supraspecific taxa of Chondrichthyan fishes. Part B: Batomorphii 4c: Order Rajiformes - Suborder Myliobatoidei - Superfamily Dasyatoidea - family Dasyatidae - Subfamily Dasyatinae - Genus: Urobatis, Subfamily Potamotrygoninae - Genus: Paratrygon, Superfamily Plesiobatoidea - Family Plesiobatidae-Genus: Plesiobatis, Superfamily Myliobatoidea - Family Myliobatidae - Subfamily Myliobatinae - Genera: Aetobatus, Aetomylaeus, Myliobatis and Pteromylaeus, Subfamily Rhinopterinae - Genus: Rhinoptera and Subfamily Mobulinae - Genera: Manta and Mobula. Addendum 1 to 4a: erratum to Genus Pteroplatytrygon. Bulletin de l'Institut royal des Sciences naturelles de Belgique, 70, 5-67.

Herman, J., Van Den Eeckhaut, G., 2010. Inventaire systématique des Invertebrata, Vertebrata, Plantae et Fungi des Sables de Bruxelles à Zaventem. Géominpal Belgica, Découvertes géologiques, minéralogiques et paléontologiques en Belgique, $1(2), 35-65$.

Hiden, H.R., 1995. Elasmobranchier (Pisces, Chondrichthyes) aus dem Badenium (Mittleres Miozän) des Steirischen Beckens (Österreich). Mitteilungen der Abteilung für Geologie und Paläontologie am Landesmuseum Joanneum, 52/53, 41-110.

Houttuyn, M., 1764-65. Natuurlyke historie of uitvoerige beschryving der dieren, planten en mineraalen, volgens het samenstel van den Heer Linnaeus. Met naauwkeurige afbeeldingen. 3 vols., (37 parts). Fishes, pts. 7 \& 8; Part 7 (1764), vi (unnumbered) + 446pp; Part 8 (1765), viii (unnumbered) $+525+57$ (unnumbered) $+30 \mathrm{pp}$.

Huxley, T.H., 1880. On the application of the laws of evolution to the arrangement of the Vertebrata, and more particularly of the Mammalia. London, Proceedings of the Zoological Society, 43, 649-662.

Iturralde-Vinent, M., Mora, C.L., Rojas, R., Gutiérrez, M.R., 1998. Myliobatidae (Elasmobranchii: Batomorphii) del Terciario de Cuba. Revista de la Sociedad Mexicana de Paleontologia, 8(2), 135-145.

Jaekel, O.M.J., 1894. Die eocänen Selachier vom Monte Bolca: ein Beitrag zur Morphogenie der Wirbelthiere. Verlag von Julius Springer, Berlin, 176pp.

Joleaud, L., 1912. Géologie et paléontologie de la Plaine du Comtat et de ses abords. Description des terrains néogènes. Montpellier, Imprimerie Montane, Sicardi et Valentin, 2, 255-285.

Jonet, S., 1968. Notes d'ichthyologie miocène portugaise. VQuelques Batoïdes. Revista da Faculdade de Ciências da Universidade de Lisboa, 15(2), 233-258.

Jonet, S., 1976. Notes d'ichthyologie miocène. VII- La famille des Mobulidae au Portugal. Boletim da Sociedade Geológica de Portugal, 20(1-2), 53-64.

Jordan, D.S., Evermann, B.W., 1896. The fishes of North and Middle America, a descriptive catalogue of the species of fish-like vertebrates found in the waters of North America, north of the isthmus of Panama. Part. I. Bulletin of the United States National Museum, 47, 1-1240. 
Jordan, D.S., Beal, C.H., 1913. Supplementary notes on fossil sharks. Bulletin Department of Geology, University of California, 7, 243-256.

Kosro, P.M., Huyer, A., Ramp, S.R., Smith, R.L., Chavez, FP., Cowles, T.J., Abbott, M.R., Strub, P.T., Barber, R.T., Jessen, P., Small, L.F, 1991. The structure of the transition zone between coastal waters and the open ocean off northern California, winter and spring 1987. Journal of Geophysical Research: Oceans, 96(C8), 14707-14730.

Last, P.R., Naylor, G.J., Manjaji-Matsumoto, B.M., 2016 a. A revised classification of the family Dasyatidae (Chondrichthyes: Myliobatiformes) based on new morphological and molecular insights. Zootaxa, 4139(3), 345-368. DOI: https://doi.org/10.11646/zootaxa.4139.3.2

Last, P. R., White, W., Séret, B., Naylor, G., Carvalho, M., Stehmann, M. (eds.), 2016b. Rays of the World. United States of America (USA), CSIRO Publishing, 832pp.

Laurito Mora, C., 1999. Los Seláceos fósiles de Ia localidad de Alto Guayacan (y otros ictiolitos asociados). Mioceno Superior-Plioceno Inferior de la Formación Uscari, provincia de Limón, Costa Rica. San José, Guila Imprenta, 168pp.

Laurito Mora, C., 2004. Ictiofauna de la Formación Punta Judas, Mioceno Medio, Provincia de Puntarenas, Costa Rica. Brenesia, 62, 57-73.

Laurito, C., Valerio, A.L., 2008. Ictiofauna de la localidad de San Gerardo de Limoncito, Formación Curré, Mioceno Superior, cantón de Coto Brus, provincia de Puntarenas, Costa Rica. Revista Geológica de América Central, 39, 6585.

Legoinha, P., 2001. Biostratigrafia de foraminíferos do Miocénico em Portugal. Unpublished PhD Thesis. Universidade Nova de Lisboa, 241pp.

Legoinha, P., Flores, J.A., 2014. Refinement of the biostratigraphy and biochronology of the Belverde borehole (Setúbal Península, Portugal) using calcareous nannofossil data. In STRATI 2013, 1119-1122.

Linné, C., 1758. Systema Naturae per regna tria naturae, regnum animale, secundum classes, ordines, genera, species, cum characteribus differentiis synonymis, locis. Stockholm (L. Salvius), ed. X., 1, 824pp.

Linck, H.F., 1790. Versuch einer Eintheilung der Fische nach den Z(a)hnen. Magazin für das Neueste aus der Physik und Naturgeschichte Gotha, 6(3), 28-38.

Martini, E., 1971. Standard Tertiary and Quaternary calcareous nannoplankton zonation. In Proc. II Planktonic Conference, Roma 1970, Roma, Tecnoscienza, 2, 739-785.

Mein, P., 2000. La biochronologie des mammifères néogènes d'Europe. Ciências da Terra, 14, 335-342.

Müller, J., Henle, J., 1837. Gattungen der Haifische und Rochen nach einer von ihm mit Hrn. Henle unternommenen gemeinschaftlichen Arbeit über die Naturgeschichte der Knorpelfische. Berichte der Königlichen Preussischen Akademie der Wissenschaften zu Berlin, 1837, 111-118.

Müller, J., Henle, J., 1838. Ueber die Gattungen der Plagiostomen. Archiv für Naturgeschichte, 4, 83-85.
Müller, J., Henle, J., 1841. Systematische Beschreibung der Plagiostomen. Verlag von Veit und Companie, Berlin, Germany, XXII +200pp.

Naylor, G.J., Caira, J.N., Jensen, K., Rosana, K.A., Straube, N., Lakner, C., 2012. Elasmobranch phylogeny: a mitochondrial estimate based on 595 species. In: Carrier, J.C., Musick, J.A., Heithaus, M.R. (eds.). Biology of sharks and their relatives. United Kingdom, CRC Press, Taylor and Francis Group, 31-56.

Pais, J., Cunha, P.P., Pereira, D., Legoinha, P., Dias, R., Moura, D., da Silveira, A.B., Kullberg, J.C., González-Delgado, J.A., 2012. The Paleogene and Neogene of western Iberia (Portugal): A Cenozoic record in the European Atlantic Domain. SpringerBriefs in Earth Sciences, 1-138. DOI: 10.1007/9783-642-22401-0.

Pollerspöck, J., Straube, N., 2018. www.shark-references.com. World Wide Web electronic publication, version 2018.

Priem, M.F, 1904. Sur les poissons fossiles des terrains tertiaires supérieurs de l'Hérault. Bulletin de la Société géologique de France, 4(4), 285-294.

Probst, J., 1877. Beiträge zur Kenntniss der fossilen Fische aus der Molasse von Baltringen. II: Batoidei A. Günther. Jahreshefte des Vereins für vaterländische Naturkunde in Württemberg, 33, 69-103.

Rafinesque, C.S., 1810. Indice d'ittiologia siciliana: ossia catalogo metodico dei nomi latini, italiani, e siciliani dei pesci, che si rinvengono in Sicilia disposti secondo un metodo naturale eseguito da un appendice che contiene la descrizione di alcuni nuovi pesci siciliani. Ill Opuscolo del Signore C.S. Rafinesque Schmaltz. Giovanni del Nobolo, Messina, 70pp.

Reinecke, T., Von der Hocht, F., Gürs, K., 2008. Die Elasmobranchier des Vierlandiums, Unteres Miozän, im Nordwestdeutschen Becken aus Bohrungen und glaziofluviatilen Geröllen („Holsteiner Gestein”) der Vierlande-Feinsande (Holstein) und der Kakert-Schichten (Niederrhein). Palaeontos, 14, 1-54.

Reinecke, T., Louwye, S., Havekost, U., Moths, H., 2011. The elasmobranch fauna of the late Burdigalian, Miocene, at Werder-Uesen, Lower Saxony, Germany, and its relationship with early Miocene faunas on the North Atlantic, Central Paratethys and Mediterranean. Palaeontos, 20, Palaeo Publishing and Library, 170pp.

Rouault, M., 1858. Note sur les vertébrés fossiles des terrains sédimentaires de l'ouest de la France. Comptes Rendus hebdomadaires des séances de l'Académie des Sciences, 47, 99-103.

Sahni, A., Mehrotra, D.K., 1981. The elasmobranch fauna of coastal Miocene sediments of peninsular India. Biological Memoirs, 5(2), 83-121.

Sharma, K.M., Patnaik, R., 2013. Additional Fossil Batoids (Skates and Rays) from the Miocene Deposits of Baripada Beds, Mayurbhanj District, Orissa, India. Earth Science India, 6(4), 160-184.

Stromer, E., 1905. Die Fischreste des Mittleren und Oberen Eocäns von Ägypten. I. Teil: Die Selachier, A. Myliobatiden und Pristiden. Beiträge zur Paläontologie und Geologie Österreich-Ungarns, 18, 163-185. 
Szabó, M., Kocsis, L., 2016. A new Middle Miocene selachian assemblage (Chondrichthyes, Elasmobranchii) from the Central Paratethys (Nyirád, Hungary): implications for temporal turnover and biogeography. Geologica Carpathica, 67(6), 573-594. DOI: https://doi.org/10.1515/ geoca-2016-0036

Vialle, N., Adnet, S., Cappetta, H., 2011. A new shark and ray fauna from the Middle Miocene of Mazan, Vaucluse (southern France) and its importance in interpreting the paleoenvironment of marine deposits in the southern Rhodanian Basin. Swiss Journal of Palaeontology, 130(2), 241-258. DOI: https://doi.org/10.1007/s13358-011-0025-4

Weigmann, S., 2016. Annotated checklist of the living sharks, batoids and chimaeras (Chondrichthyes) of the world, with a focus on biogeographical diversity. Journal of Fish Biology, 88(3), 837-1037. DOI: https://doi.org/10.1111/jfb.12874

Weigmann, S., 2017. Supplementary Table II (as of November 26, 2016) of Annotated checklist of the living sharks, batoids and chimaeras (Chondrichthyes) of the world, with a focus on biogeographical diversity by Weigmann (2016). Journal of Fish Biology, 90, 1176-1181. DOI: 10.1111/jfb.13234

White, E.I., 1926. Eocene fishes from Nigeria. Bulletin of the Geological Survey of Nigeria, 10, 1-82, 20 fig., pl. 1-18.

White, E.I., 1934. Fossil fishes of Sokoto province. Bulletin of the Geological Survey of Nigeria, 14, 1-78, pl. 10.

White, E.I., Moy-Thomas, J.A., 1941. Notes on the nomenclature of fossil fishes. Part III: Homonyms M-Z. Annals and Magazine of Natural History, Series 11, 7, 395-400.

Whitley, G.P., 1936. The Australian devil ray Daemomanta alfredi (Krefft) with remarks on the superfamily Mobuloidea (Order Batoidei). Australian Zoologist, 8(3), 164-188.

Zalmout, I.S., Antar, M.S., Shafy, E.A.E., Metwally, M.H., Hatab, E.B.E., Gingerich, P.D., 2012. Priabonian sharks and rays (late Eocene: Neoselachii) from Minqar Tabaghbagh in the Western Qattara Depression, Egypt, Contributions from the Museum of Paleontology, University of Michigan, 32(6), 71-90.

Manuscript received March 2018;

revision accepted May 2019;

published Online July 2019. 